\title{
Belphégor
}

\section{Before the "Comics": On the Seriality of Graphic Narratives during the Nineteenth Century}

\section{Federico Pagello}

\section{(2) OpenEdition}

\section{Journals}

\section{Electronic version}

URL: http://journals.openedition.org/belphegor/810

DOI: 10.4000/belphegor.810

ISSN: 1499-7185

\section{Publisher}

LPCM

\section{Electronic reference}

Federico Pagello, "Before the "Comics": On the Seriality of Graphic Narratives during the Nineteenth Century », Belphégor [Online], 14 | 2016, Online since 31 October 2016, connection on 19 April 2019. URL : http://journals.openedition.org/belphegor/810; DOI : 10.4000/belphegor.810

This text was automatically generated on 19 April 2019

\section{(c) (†) $\odot$}

Belphégor est mis à disposition selon les termes de la Licence Creative Commons Attribution - Pas d'Utilisation Commerciale - Pas de Modification 4.0 International. 


\title{
Before the "Comics": On the Seriality of Graphic Narratives during the Nineteenth Century
}

\author{
Federico Pagello
}

1 According to historians, by the early 1890s the colloquialism "comic" had become common usage to describe the humour magazines publishing graphic narratives in the UK (Carpenter 1983: 74), whereas in France the expression "bande dessinée" (the equivalent of "comics)" was only gradually adopted between the 1930s and the 1950s (Grove 2005: 43-44). While highlighting the different national histories of the medium and two distinct moments in its international evolution (i.e. the appearance of a new type of illustrated magazines in the late Victorian age, and the ultimate success of the Americaninfluenced comic strips four decades later), both these linguistic phenomena reflect one single overarching process: the institutionalisation of the medium of comics between the end of the nineteenth and the middle of the twentieth century.

2 This late-nineteenth, early-twentieth-century phase came after a period in which the potentialities of graphic narratives had been explored for various decades. What was lacking in this early period was not simply a label but the complex linguistic and institutional (infra)structure which allows, and justifies, the process of labelling a new means of expression, transforming it in a medium in its own right. Even if a vast array of graphic narratives existed in the nineteenth century, their place in the literary, artistic and publishing fields remained unclear, eventually preventing the form from developing further and thus acquiring a more recognisable identity. Various crucial linguistic elements contributed to turning the unstable semiotic system of nineteenth-century graphic narratives into the now familiar language of comics, including the elimination of the accompanying text, the development of a visual grammar which resembles (and anticipated) movie editing, the common use of balloons, etc. One of the key features of this new identity, however, was an extraordinarily intense process of serialisation. Although serial graphic narratives can be found starting in the late 1830s, these earlier 
examples of "comics" remained hybrid entities: they formed an integral, but still marginal part of the satirical, illustrated and humour press in which other forms of popular visual culture, such as caricature and illustration, were largely hegemonic. Interesting cases of serialisation can be found within this production. However, they should not be anachronistically compared with the future comics, but rather examined in relation to their contemporary context.

In this paper, I aim to examine this early nineteenth century period. I start by briefly discussing the strong connection between comics and seriality in the twentieth century. I will then examine the role of seriality at a few key moments in the history of nineteenthcentury graphic narratives in Europe: the theory and practice of the Swiss Rodolphe Töpffer (1830s); the works of his earliest French followers, such as Cham, Nadar and Doré (1840s); the multiple typologies of serial comic strips published in various countries between the 1860s and 1880s; and the series published in the Parisian magazine Le Chat noir (1882-1895). By offering a panoramic account of this phenomenon, my goal is to highlight the richness and diversity of serial graphic narratives during this historical period, and to explore the reasons why their intertextual and paratextual relationship to the rest of nineteenth-century print culture might help to identify their distinct identity, in comparison to twentieth-century comics.

\section{The (un)questionable connection between comics and serialisation}

In his The Children of the Yellow Kid (1998), R.C. Harvey discussed the rationale behind the then traditional definition of Richard Outcault's strip Hogan's Alley (first published in 1895) as the "first comic." Harvey draws on Colton Waugh's pioneering The Comics (1947), in which the Yellow Kid comics was regarded as the symbolic point of departure for the whole medium because of the simultaneous use of three different elements for the first time: "1) a narrative sequence of picture in which 2) speech balloons are included in the drawings, the combination showcasing 3) a character or characters who reappear with each publication of the feature" (Waugh 1998: 20). While this narrow definition of comics has been convincingly challenged for historical and theoretical reasons (Kunzle 1990; Groensteens and Peeters 1994; Smolderen 2009), I want to focus here on the reasons why its influence is deeply related to what might appear as possibly its weakest aspect: the importance of the use of a recurring character, i.e. of a serial structure. As Harvey points out:

"this last quality seems [...] to be somewhat trumped up. The first two aspects of the medium are rooted in its form; the third refers to content. Clearly a narrative sequence of pictures in which the characters speak by blurting out what they have to say in puffs of dialogue called "speech balloons" is a comic strip whether or not the characters appear again and again. The character qualification was probably tacked on in order to eliminate all the predecessors to the Yellow Kid" (Harvey 1998: 20).

5 As a matter of fact, even if Harvey's argument is historically inexact (Kunzle 1990, Sabin 2003 and others have studied examples of 19th-century recurring comic characters), it points to the real core of Waugh's discourse, whose aim was to support the idea that the birth of modern comics coincided with the appearance of (American) newspaper strips and their peculiar narrative formula. This is why his definition of the form included 
narrative serialisation: it was only through this mix of apparently disparate ingredients that it became possible for the first (American) comics critics to claim that the object known as comics reached a stable and definite identity only at the turn of the century (in the United States), eventually establishing its autonomy from other genres of cartoons and picture stories. After all, Waugh's empirical definition of what comics are might appear quite adequate to describe what the (American) "common reader" would recognize as "a comic" when The Comics was first published". Waugh's discourse thus reflects the crucial role played by serialisation in the early and mid- $20^{\text {th }}$-century experience of comics and highlights how the publication and reading practices deeply affected the (social) identity of the medium.

In their brilliant edited collection entitled La Bande Dessinée: Une Médiaculture (2012), Eric Maigret and Matteo Stefanelli argue that during the last two decades the debate about the "origins" of comics has been reframed according to a more rigorous historical and theoretical apprehension of its subject. On the one hand, our better knowledge of the slow and uneven evolution of the techniques, technology and language of graphic narratives since the late $18^{\text {th }}$ century prevents us from indulging in an endless quest for the "first comic"-not to mention any meaningless dispute about its nationality-and lets us embrace the idea of hybridity and ongoing change as part of the definition of comics. On the other hand, Maigret and Stefanelli prompt us to think of what has been known as "comics" for most of the $20^{\text {th }}$ century as a specific version of the complex dispositif (in the specific, and hardly translatable, Foucaldian-Deleuzian meaning of this term), which is determined precisely by a series of textual and non-textual components. It is for this very reason that Maigret and Stefanelli, while fostering further research in the development of the language of (European) comics in the two previous centuries, still consider the (American) twentieth-century comic strip as a decisive moment in the evolution of the comics medium. What made American comics so important was precisely, first of all, the institutionalisation of a whole system of production and consumption. The extensive practice of narrative serialisation played a major role in this context: the creative process, the industrial production and distribution, the editorial practices and, finally, the experience of comics readers all underwent dramatic changes when comics started to develop an identity distinguished from satirical cartoons, illustrated books and the various forms of children's picture stories. It is not by chance that this new identity appears to coincide with the new hegemony of the serial strip, first in the comic genre, then with the adventures and sci-fi stories of the late 1920s/early 1930s, and, finally, the birth of the comic books devoted to the adventures of a single character. It was thanks to the synergy between these two processes that during their "golden age", in the first half of the twentieth-century, this specific type of graphic narrative was eventually identified as a separate medium called "comics".

7 André Gaudréault and Philippe Marion (2005) have proposed a historical-theoretical model to describe what they called the "double birth" of media. According to their analysis every medium has experienced a similar delayed, two-phase process. In fact, Gaudréault and Marion distinguish three stages in the "coming of age" of a medium: the appearance, the emergence, and the constitution. Using cinema, photography and (interestingly) comics as examples, they show how any new technology or means of expression needs to develop its own, autonomous language and institutional framework before being able to present itself as a proper medium. The case of comics is particularly revealing in this sense, at least in comparison to the relatively rapid institutionalisation 
of cinema, which took about twenty or thirty years: if we agree with many contemporary scholars who see in the works of Rodolphe Töpffer, in the 1830s and 1840s, both a symbolic and an actual point of departure (i.e. the moment of the appearance of the modern comic strip), this intermediate, explorative, and uncertain phase of emergence lasted for at least sixty years.

While the role of serialisation in the institutionalisation of comics has been discussed extensively by several comics scholars (including Olivier Odaert in another article included in this issue of Belphégor), much less attention has been given to this previous phase. It would be a mistake, however, to think that no form of serialisation could be found until the end of the nineteenth century: even if far rarer than in the years that followed, a number of interesting examples of serial graphic narratives were published in this period of comics' "appearance."

\section{From Töpffer to the "Collection des Jabots"}

While it remains an ongoing subject of debate, ${ }^{2}$ the crucial role played by Töpffer's work in the evolution of nineteenth-century comic art is indisputable. As Kunzle (2007) and Groensteen and Peeters $(1994 ; 2014)$ have argued, the Swiss author has to be regarded as a key figure in comics history not only because he created and theorized a number of essential features of modern comics, but also because he clarified his intentions. What is more striking in his work is indeed his awareness of the nature and the potentialities (at the time still unrealized) of the litter rature en estampes that he was sketching out: it is because of this aspect of his work that scholars have been tempted to call him "the inventor" of the whole medium of comics, regardless of whether this is entirely historically or theoretically exact. What, then, can this crucial figure teach us about the role of serialisation in the identity of early comics and about its putatively marginal place in nineteenth-century graphic narratives?

First of all, Töpffer's theory and practice prove that narrative serialisation was not one of the essential characteristics of the comic strip at this time. Engaged in developing his original language, combining the various influences of the English caricaturists, the images d'Epinal, and the seventeenth-century (comic) novel, Töpffer's theoretical reflection was mainly focused on problems concerning this means of expressions and its potential as regards specific narrative styles, registers and genres, whereas his interest for the industrial uses of this language was virtually nonexistent. This approach has multiple consequences in relation to Töpffer's relationship to the future developments of the comics strip. On the one hand, he never explored the possibility of using formats other than the album: Töpffer chose this format assuming it to be the ideal form for his creations, and, despite his involvement in the serialisation of one of his works in a magazine (which I will discuss in the following section), he did not personally explore this opportunity. On the other hand, he remained theoretically faithful to the model of the "traditional" self-contained novel, and did not think of his creations as a potential equivalent to the serialised products that were becoming so popular during the same decade (the 1830s) in which he started to publish his works.

11 Töpffer's choice was neither innocent nor obvious. Simply by stretching his narratives to the length of a whole album, he made one of the key moves toward establishing the autonomy of his graphic narratives, one that was distinct from the tradition of caricature and the broadsheet. As Groensteen has pointed out (1994: 93), the chance of expanding 
their stories to such length had never been granted to artists such as Hogarth and to the authors of popular prints: by allowing the narrative to unfold throughout tens of pages, the töpferrian album represented a major departure from his precursors and pointed to a structural aspect of the new form: that is, the ability to fully develop a relatively complex narrative. In fact, Töpffer picked up the well-known format of the caricature album (his own father, Adam, had published one such work, entitled simply Caricatures, in 1817) and used it in a very different way. As the excerpt from his Essai de physiognomonie (1845) clearly shows, Töpffer's interest in this format implied the desire to create a cohesive work, a "book" (and a "novel"), in open opposition to other type of texts:

Faire de la littérature en estampes, ce n'est pas se constituer l'ouvrier d'une donnée pour en tirer, et jusqu'à la lie souvent, tout ce qu'elle comporte. Ce n'est pas mettre au service d'une fantaisie uniquement grotesque un crayon naturellement bouffon. Ce n'est pas non plus mettre en scène un proverbe ou en représentation un calembour: c'est inventer réellement un drame quelconque, dont les parties coordonnées à un dessin aboutissent à faire un tout; c'est, bon ou mauvais, grave ou léger, fou ou sérieux, avoir fait un livre, et non pas seulement tracé un bon mot ou mis un refrain en couplets (my italics; Groensteen $2014: 189$ ) 3 .

In this respect, therefore, Töpffer might be better seen as a precursor to the contemporary "graphic novel" than a forefather of the "classical" comics, something which certainly confirms the hypothesis of a double birth of the comics "medium". Alternatively, this suggests that the Swiss author may have baptised two "media" at once, since the graphic novel had to see its own "institutionalization", i.e. its (much debated) "distinction" from "comics", only during the 1980s and 1990s.

This, however, is not the entire story. First of all, it must be noted that his Réflexions à propos d'un programme-Töpffer's most substantial theoretical contribution to the field together with his Essai de physiognomonie-terminates with a lengthy analysis of the advantages of using recurring characters. The interesting way in which this piece prefigures the future of serial heroes in the field of comics justifies its reproduction in full here:

Nous avons entrevu plus haut, sans nous y arrêter, que certaines figures arrivent à devenir des types populaires: ainsi les images proprement dites, ainsi Mentor, Télémaque, ainsi quelques autres. Ces types sont les résultats de traditions ou de conceptions antérieures, et l'on peut douter qu'il soit possible de créer des types artificiellement, indépendamment de toute tradition, de toute conception antérieure. L'essai vaut au moins la peine d'être tenté; car là réside un grand moyen d'action sur les esprits, moyen d'autant plus efficace qu'il soulage l'intelligence et l'attention du spectateur, tout en lui permettant de saisir une idée plus compliquée et plus étendue.

Que l'on suppose, par exemple, que Télémaque ne soit pas un type donné, défini par le livre de Fénelon, et dont l'artiste ne peut user que conformément à ce livre; qu'il fut au contraire un type librement créé par l'artiste, et dont l'artiste peut, par conséquent, se servir de mille manières, qu'il peut mettre dans mille situations, quel avantage n'est-ce pas pour lui que de faire agir dans ses représentations, au lieu d'une figure nouvelle et abandonnée à chaque fois pour une autre avant d'avoir être complètement saisie, une figure connue, familière à l'esprit, dont son public connaît le caractère et la moralité ; dont déjà, avant de la voir agir, il sait les précédents, il apprécie les motifs? Une pareille figure, une fois créée, ne nécessite nul besoin d'exposition, nul besoin même d'appareil, de combinaison, de série régulière pour les estampes; car chacune d'elles devient l'acte nouveau d'un même drame, par le fait seul que tous les antécédents sont connus, que cet acteur qui paraît, il suffit qu'il agisse, et que nous tenons toujours le fil par lequel son action présente se rattache à sa vie passée. 
Les types ont encore ceci de particulier et d'avantageux qu'ils deviennent bientôt du domaine de tous; que créés, compris, ils appartiennent plus à l'art que à l'artiste; que tous s'en emparent, les perfectionnent, les développent d'après la donnée première ; en telle sorte que la pensée première s'enrichit des efforts, du talent, de la pensée de tous, au lieu d'être restreinte aux conceptions bientôt épuisées d'un seul.

$\mathrm{Au}$ fait, et dans un certain sens, tout est type dans les représentations de l'espèce de celles qu'indique le programme, car il s'agit du bien et du mal, du vice et de la vertu : votre personnage vicieux n'est qu'un type, c'est-à-dire une figure ayant les caractères de l'espèce, plutôt que ceux de l'individu; et de même votre figure vertueuse. Ce que nous croyons, c'est qu'il y a de l'avantage, une fois que cette figure est bien et fortement caractérisée, à ne pas l'abandonner pour en former une autre ; qu'il vaut mieux, sans changer l'être, varier les situations, les circonstances ; développer, compléter, que changer à la fois et l'être et les circonstances (Groensteen $2014:$ :217-218) 4 .

14 This single text assigns to the (re)use of well-known characters a role which anticipates the crucial function that it seems to have actually had, a least a posteriori, in the transformation of comics into an autonomous medium at the beginning of the following century.

In fact, Töpffer himself had developed his own project to publish a sequel of one of his works (in his correspondence he mentions the intention of creating a follow-up to his Mr. Crépin, entitled Mr. Crépin à Vichy), but he couldn't put it into practice before his early death at the age of 47 . However, the very first "early adopter" of his "invention", the French publishing house Maison Aubert, was quick enough to steal some of the Swiss original works and then turn them into the first "series" of (self-contained) "graphic novels". The Collections des Jabots, including a total of 12 volumes published between 1839 and 1847 (one year after Töpffer's death), debuted with the pirated editions of Töpffer's Mr. Jabot, and Mr. Crépin and Mr. Vieux Bois, and continued with ten variations on the form and contents of these models by French authors such as Cham, Edmond Forest and Gustave Dorés. Aubert's initiative was not just the imitation and the multiplication of a successful product: by marketing these volumes as part of a series (the term "collection" in French refers exactly to a specific "series" of books created by a publisher), it displaced Töpffer's ambition of creating a littérature en estampes into the more prosaic language and practices of the publishing industry. The publishing house Aubert had been created in 1829 by the caricaturist Charles Philipon, who was also an important publisher of satirical journals, together with his brother in law Gabriel Aubert. Philipon's and Aubert's pioneering decision to invest in this brand new form of graphic narrative is thus to be seen as a crucial moment in the history of the comic strip. Even if its attempt proved valid only several decades later, Aubert's not entirely successful commercial enterprise immediately revealed the potential of Töpffer's 'invention' for an industrialised, i.e. serial, use.

16 This "failure" of Aubert to compose its "graphic novels", and more broadly, to make the serial comic strip the pervasive phenomenon it would become at the end of the century, is extremely significant. It suggests, perhaps, that Töpffer's disinterest in a more intense exploitation of this language in the book or periodical industries might have been a symptom of its being out-of-place within the commercial publishing market of the time. Patricia Mainardi, for example, tried to explain this phenomenon as follows:

Aubert did continue to publish collections of individual caricatures, however, often on a single theme but with no continuous narrative. It is not difficult to understand why these early comics had only a limited success: though ephemeral literature, 
they demanded too much concentration from the reader and really needed to be read at one sitting, while albums of collected caricatures, in contrast, could be enjoyed even if the reader had only a few moments available. Unlike Töpffer's albums, which often satirized contemporary society and as such were intended more for adults than for children, the early French comic book seemed to be an art form unsure of its audience. Too expensive and too long for children, their stories weren't interesting enough to attract adults. Collections of individual caricatures were more sophisticated and topical and, as a result, proved more attractive to an adult audience (Mainardi 2007).

Whatever the reason(s), it is a fact that the combination of graphic narratives and serialisation remained rare in this period. At the same time, however, Töpffer's work and that of his first disciples fruitfully influenced the evolution of the illustrated humour magazine in the following decades, launching the long series of experimentations that characterized the phase Gaudréault and Marion have called "emergence".

\section{The first experiments with graphic narratives as serialised texts}

Studies in early comics identify the earliest important followers of Töpffer during the 1840s and early 1850s as a group of French cartoonists. According to comics historians, Cham (Amédée de Noé), Gustave Doré, and, less importantly, Nadar (Gaspard-Félix Tournachon) were the most original and successful artists to develop the new form in this period (Kunzle 1990; Groensteen 2000; Smolderen 2009; Willems 2012). Most relevant to this article, they all contributed to establishing a stronger connection between graphic narratives and serial strategies, helping to move Töpffer's model from the book market into the realm of satirical and humour periodicals. Crucially, these authors created some of the first examples of graphic narratives published in instalments. In addition to publishing a number of "töpfferian" albums (including Cham's and Doré's contributions to the above mentioned "Collection des Jabots"), these artists were featured in popular magazines such as Le Charivari (1832-1937), L'Illustration (1843-1944), La revue comique à l'usage des gens sérieux (1848-1849) and Le Journal pour rire (1848-1855, later entitled Le Journal amusant, 1856-1933).

19 The migration of Töpffer's work into this new context coincided with the serialisation, between January and April 1845, of the re-drawing by Cham of his unpublished story Mr. Cryptogame, for the most important French illustrated magazine of the mid-nineteenth century, L'Illustration. Contrary to Aubert's pirated editions, this version of Töpffer's work was authorized by the author. Töpffer personally gave detailed instructions to his French colleague on how to approach his graphic style ${ }^{6}$. Despite its important symbolic value, however, this new edition of Cryptogame did not represent the beginning of a regular presence of graphic narratives in L'Illustration, nor was it the first serialised comic strip in a French magazine. In fact, from December 1844 to January 1845, Le Charivari had already published Voyage de Paris en Amérique, once again by $\mathrm{Cham}^{8}$. The same artist would continue to contribute serial stories to Le Charivari for the next few years, starting with a sequel of Voyage de Paris, whose twenty instalments first appeared in 1845 and were later collected in an album entitled Nouveaux voyages et nouvelles impressions lithographiques, phylosophiques \& comiques de M.M. Trottman et Cham (Aubert, 1846). A few years later, Nadar experimented with the graphic narrative in La revue comique, with three serial stories, the best-known of which is Vie publique et privée de mossieu Réac, formed of thirteen parts, 
released between March and July 1849. Doré was the author of various short stories featured in Le Journal pour rire, his most ambitious serial work being L'Homme aux cent-mille écus, written by E. Bourget and published in five episodes in 1850. Le Journal pour rire and Le Journal amusant proved to be the main vehicle for the new form in mid-nineteenthcentury France. They hosted a number of serial graphic narratives created by artists such as Forest, Monta, M. Guesde, and Morin, who contributed serial stories influenced by the pioneering works of Cham, Nadar and Doré.

While this production shows the significance of serial and non-serial graphic narratives as a training arena for the many French cartoonists working in this period, most of these works were very short stories, containing only a few episodes, often published on an irregular basis, and presenting only weak narrative threads. Thus, these texts represent a negotiation between Töpffer's innovative works and the language of the satirical and illustrated press, rather than a full adoption of the theory and practice of the Swiss author. Consequently, these texts cannot be seen either as the origin of a fully developed tradition of serialised comic strips, or as the consolidation of a truly narrative genre. Unlike Töpffer's "novels", they remain closer to the genre of caricature than to a cohesive narrative text, based on sophisticated characters and complex narrative techniques.

A telling symptom of this hybrid nature is the important role that the topic of travel plays in many of these works9. On the one hand, as argued by Camille Filliot (2012), the relationship between the travel story and serialisation is a structural one. The travel story provided a coherent theme and a recurring character, without requiring the creation of strong continuity between different episodes. Thus, it offered a means of assembling a series of semi-independent, semi-narrative, scenes. On the other hand, the travel story was not only a well-established genre in the history of literature, but also a particularly popular one within the nineteenth-century periodical press. Shared references to travel linked many comics to each other and to other media, and this intertextuality served as an essential serial strategy: the use of a series of topoi from the travel genre gave coherence and, therefore, a more recognisable identity to these otherwise unusual works. In fact, Töpffer himself had made use of this theme: significantly, he had borrowed it from Rowlandson's trilogy of illustrated novels, $\mathrm{Dr}$ Syntax, published between 1809 and 1821. The common generic affiliation of most of these works is thus to be considered the first, macro-textual serial strategy to shape an identity for the comics field.

This ambivalent situation was not limited to France. Although picture stories were to appear in the next few years in German and British magazines, none of these experiments led to a widespread use of graphic narratives or a real development of their narrative potential, let alone the regular use of serialisation. As Philippe Willems recently pointed out in an article investigating the French satirical magazines of the 1840s, when studying the role of early comics in nineteenth-century print and visual culture, it is necessary to question the relationship between the increasingly popular "panoramic" uses of multiple images and the much rarer "sequential" (i.e. narrative) images. These can be seen as the two poles of the "serial' (i.e. multiple) image (Willems 2012). Observing how authors like Nadar or Cham quickly abandoned the graphic narrative genre to focus on thematic collections of caricatures such as the famous series of the satirical "Salons", or the monthly, quarterly or yearly "reviews" of the most important public events ${ }^{10}$, Willems argues that this phenomenon should be considered as: 
emblematic of a tensions between two axes of nineteenth-century culture: the sequential, whose manifestations put the comic strip in league with the serial novel and the kinetoscope, and the panoramic, understood since Walter Benjamin as uniting dioramas, studies of manners, and universal exhibitions (Willems 2012). images highlights both the uneven development of the graphic narrative in this period and the role of seriality within this process. Strategies of serialisation were at the core of the "panoramic ensembles" found in most works by Töpffer's early followers, whether or not a narrative was involved. Within a single ensemble, we inevitably see variations on the same image. More importantly, the recurring and regular appearance of these series of caricatures constituted a fundamental switch from the use of a self-contained caricature, or graphic narrative, to the use of well-structured collections of interrelated images. As Willems points out, a "serial image" can indeed be either a "series of vignettes forming a narrative (sequential images) or series of single pictures forming a collection around a same theme over several pages or issues of a publication (panoramic images)" (Willems 2012).

What this phenomenon shows is that "graphic narratives" were not a privileged object of interest for these artists, or, most likely, for their public. The reason why graphic stories did not become an independent genre during this period is that another (serial!) form of interaction between images occupied centre-stage. In this respect, it is certainly symptomatic that Töpffer's three most successful followers not only gave up their attempts to establish the new narrative form, but also found long-term glory in other genres and media based on different uses of the serial image, such as caricature (Cham), illustration (Doré) and even photography (Nadar). While graphic narratives were already an identifiable genre since the second half of the 1840s, and had developed techniques of serialisation that may have supported higher narrative ambitions, the dominant aesthetics of this age clearly favoured non-narrative uses of the "serial image". Some of the works that we might look at as "pre-comics" should thus be seen against this background: as Willems point out in relation to Nadar's works, their underlying logic was less clearly that of a narrative than of a collection of caricatures bound together by a recurring character and a series of common themes. As scholars of early cinema have shown (e.g. Gunning 1986), our anachronistic knowledge of the future of a medium may prevent us from interpreting in the right way the real role of narration in works produced during its phase of "emergence".

\section{The multiple forms of graphic narrative serialisation between the 1860 s and the 1880s}

In order to revise our contemporary assumptions, it is necessary to consider this uneven history and the numerous modes of serialisation characterizing the emergence of graphic narratives in the 1860s, 1870s, and 1880s. At least three major typologies of serial comicstrip texts can be observed in this period.

First, as British comics scholars have pointed out (Gifford 1977; Carpenter 1983), a few important examples of recurring characters can be found in the English context. The most popular and long-lived comic character of the whole century was the working-class anti-hero Ally Sloper, the creation of Charles H. Ross and Marie Duvall, who first appeared in 1867 on the pages of Judy (1867-1910) and was then promoted to his own 
magazine, Ally Sloper's Half-Holiday (1884-1916) (Kunzle 1986; Bailey 1983). Sloper was not only the regular feature of a periodical publication, but was soon to become a multimedia phenomenon. In addition to over a hundred pages of self-contained short stories (onepage long each) and many illustrated volumes collecting these stories, he was the subject of theatrical performances, magic lantern shows, and short silent films (Sabin 2003). This character proves the success of a recurring figure within the medium of graphic narratives and anticipates the future success of comics heroes as transmedial icons. Indeed, Sloper's adoption in so many contexts testifies to his lasting and pervasive fame, which is particularly evident in merchandising campaigns. These campaigns took the form of prizes offered to the readers of the magazines in which he was featured. Further, unauthorised, exploitative uses of the character sold all sorts of objects, including "paperweights, mugs, door stops, walking sticks, bits of treen, vesta cases, tie pins (...), vending machines, crested china busts, puppets, and a number of games" (Sabin 2003).

The huge number of texts and products featuring Sloper remains the ultimate evidence that serial graphic narratives might have been enormously profitable in this period. Yet, they provide at the same time one more reason to wonder why only very few tried to replicate this example. Ross and Duval's creation, however, was not an absolute exception. Another series appeared on the pages of Judy is often mentioned by scholars (e.g. Kunzle 1990: 322-324): McNab of That Ilk, by James Brown. It was devoted to the exploits of a heavily caricaturised Scottish man, and it ran in Sloper's own original magazine for as long as 12 years, between 1876 and 1888. In addition, scholars frequently make reference in this context to the creations of one of the main English cartoonists of this period, James Sullivan. His volumes British Working Class Man (1878) and The British Tradesman (1880), collecting a series of strips focusing on this emblematic figures of Victorian society, appeared for several decades in the highly popular magazine Fun (1861-1901), from the mid-1870s until the end of the century (see Kunzle 1990: 324-329). However, they tended to follow the typical satirical strategy of creating abstract "types" to be regularly revisited, rather than inventing real characters.

Various other serialised stories continued to be published during these years, especially in French and German magazines such as the aforementioned Le Journal amusant and the seminal Fliegende Blätter (1845-1944). Interestingly, one of the comic artists regarded by historians as among the most relevant of this period, the French Léonce Petit, was constantly engaged in creating serial graphic stories. His major work, the 36 Histoires campagnardes published between 1872 and 1882 on the pages of Le Journal Amusant, combined the thematic unity of the traditional caricature with the technique of the feuilleton, often presenting stories divided in three or four episodes. The same solution was used by Petit in other works, such as an adaptation of Champfleury's Monsieur Tringle, published in three episodes in Le Journal amusant (1867); Les Mésaventures de M. Bêton, appeared in Le Hanneton between March 1867 and August 1868 and concluded in L'Eclipse in $1868^{11}$; Comment on devient réactionnaire ou Les palinodies d'Agénor Pistochard, was published in four episodes in Le Grelot (1867) ${ }^{12}$. As Kunzle points out (1990: 159), the amount of space occupied by Petit's Histoires campagnardes in the leading French magazine presenting graphic narratives was unusual, ${ }^{13}$ proving once again how much this type of serial products were appreciated by readers.

Finally, it is necessary to examine the third and most common type of seriality in this period. This specific type of seriality is shaped by the structure of the periodicals in which graphic stories appeared. To understand this structure, it is necessary to look at the 
relationship between the single strip and the paratext. This relationship creates thematic and stylistic continuity between self-contained short narratives. The most important example of this form is to be found in the work of Wilhelm Busch, by now generally regarded as the second "pioneer" of the modern comic strip after Töpffer ${ }^{14}$, and who became the most internationally influential author precisely during this period. Busch's works offer a model for the widespread use of self-contained, one-page stories in graphic narratives published between the 1860 s and the 1880 s. The adoption of this format was not the result of an idiosyncratic decision by this creator, but the consequence of the standards adopted by the German publishing market for which he worked. While he also used the album format, many of Busch's works first appeared in the Münchener Bilderbogen , a series of unrelated broadsheets published biweekly by Verlag Braun \& Schneider between 1848 and 1898. This forum forced the author to restrain his storytelling to one single page. Moreover, Busch's other main publisher was the leading German comic magazine, Fliegende Blätter, which typically presented self-contained one- or two-page illustrated stories. Since its early years, this magazine often included one full page featuring various types of graphic narratives ${ }^{15}$. More often than not, a single story would fill the whole page, sometimes expanding to the length of two pages. While narrative serialisation remained largely exceptional in this magazine, and always very limited, the presence of these works as a regular feature might be seen as an attempt to serialise the graphic narrative as far as the structure of the periodical was concerned, without imposing too narrow a logic of narrative serialisation onto the picture story. By accumulating these short stories, this structure allowed for a sort of synthesis between the "sequential" and the "panoramic". In fact, Fliegende Blätter did not present the large collections of thematically connected images cherished by French magazines like Le Journal pour Rire. The only alternatives to these graphic narratives were the more traditional illustrated texts or single images, usually accompanied by a short text. Further, these illustrated texts were the most common visual feature of the periodical.

The increasing adoption of this model in other European countries could also perhaps be seen as the link the earliest example of serialised graphic narratives and the comic series that would take shape in the 1890s. In the 1860s and 1870s, English magazines such as those previously mentioned, as well as French publications such as Le Journal amusant (1855-1933), La Lune (1865-1868), L'Eclipse (1868-1876), L'Image (1868-1870), Le Monde Comique (1869-1898), or La Vie Amusante (1877-1891), all featured graphic narratives on a regular basis. Graphic narratives gradually became an integral part of the illustrated periodicals published in Europe in this period, even though written texts, illustrations, single caricatures and "panoramic" groups of images still clearly had the upper hand. It is therefore important to recognise that the association between the form of the graphic narrative and the serial logic of the print industry was established from the very beginning, or, more precisely, from the moment when the "original" album format proved to be not suitable for serialisation.

31 This close relationship between the modern comic strip and the economic logic of the periodicals industry also manifests itself in the example of non-fiction, and even nonnarrative, comic strips of the 1860s/1880s period. Thierry Smolderen (2012a and 2012 b) has only recently 'rediscovered' significant representatives of this almost entirely forgotten production in the two leading British illustrated magazines of the Victorian age: the Illustrated London News and The Graphic. These surprisingly sophisticated comic pages, often representing real events or travel reports drawn in a realistic style, initially 
appeared during the 1870s in the Christmas or Summer special issues of the two magazines, and they later became a more regular feature. In the case of The Graphic, in particular, they would be even used on the front page, proving that they were considered particularly appropriate to convey the magazine's contents and identity. The choice of this means of expression in association with specific marketing operations (the special issue) or key features of these magazines (the cover page) highlights a cautious but regular adoption, which indicates a conscious strategy of serialisation.

In addition, it is interesting to notice the return of one of the privileged topics of the earliest serialised graphic narratives: the travel genre. In The Graphic, although the subject changed in each occurrence, we do find a double repetition. On the one hand, the serial form is associated with the travel genre, which is a way of establishing continuity between this particular feature of the magazine and its content. On the other hand, in the case of The Graphic, these comic strips became a regular, interactive way of attracting an audience eager to see their own experiences turned into comic strips by the magazine's artists, since readers were invited to submit notes and sketches about their own travels as inspiration.

Yet one more example of this specific use of the form can be found in another crucial English periodical, the famous Illustrated Police News (1842-1938). As in the case of the aforementioned illustrated magazines, the use of non-fiction and non-narrative comic strips became more and more frequent. The front page of this magazine, initially featuring a single illustration and a lengthy written text, was increasingly taken over by pictures, and the text was quickly reduced to just a few lines. In the course of the 1870 s the cover featured an average of 7-8 unrelated pictures, each one depicting one of the "true crimes" reported in the magazine. From the early 1880 s on, some of these images started to be connected to one another, first through thematic unity, then by a more cohesive temporal sequence, with each drawing detailing a different phase of the same event. The front page almost always featured more than one single piece of news, and never aimed to create a fully-developed graphic narrative. However, the paper's increasing reliance on this new mode of visual reportage shows that, at this stage, the comic strip was recognised by the periodicals industry as highly attractive for the public, especially when used in relation to specific paratextual features and iterative practices aiming to reinforce the identity and appeal of these publications.

\section{The first modern(ist) comic series?}

It is therefore clear that, long before the 1890s and 1900s, graphic narratives had become an increasingly regular feature of a number of illustrated and humour magazines in many European countries. Referring to the peripheral case of Belgium, for instance, Pascal Lefèvre writes:

At first the number of strips was still limited, but by the 1880 s comics and cartoons, often featured on the back page, had become an integral part [of the illustrated magazines]. Though Belgische Illustratie and Le Journal Illustré belge had been published since 1868, De Zweep since 1869 and L'Illustration Européenne since 1870, it was not until 1877 that the first narrative comic was published in such a magazine. Subsequently, more and more weeklies appeared carrying comics, so that by the end of the 1880s they were a typical feature of illustrated magazines (Lefèvre 2009: 26). 

only as far the most important comic magazines were concerned. As Kunzle explains:

The folio-sized papers of the pre-war era were succeeded by a smaller, cheaper, almost wholly pictorial format, the ten-centime quarto, typified by the Monde Comique, the earliest rival of the Petit journal. Not only was the Monde Comique one of the first to carry a regular coloured front page, but it also institutionalized the comic strip at lower price and artistic level; in content as well as price, then, it evidently appealed to the lower classes. The Monde Comique for 1874-1875 carries nine comic strips, and the incidence rises thereafter, until by the early 1880 s every second or third issue carried one. The strips are of a new type - shorter, often confined to a single magazine issue, but dominating that issue absolutely by filling all seven editorial pages (the eighth page was for advertisements). By the mid 1880s, the magazine had more pages of comic strips than of other graphics, and it continued thus to its end in 1898 (Kunzle 1990: 175).

Since this decade might be seen as the final phase of the emergence of the new medium (using Gaudréault and Marion's terminology), it is not surprising to notice the first appearance of some of the characteristics of the late 1890s serial comics. In fact, one of the most influential sources for a number of late nineteenth-century European comic magazines was the Parisian magazine Le Chat noir, the weekly publication of the famous Montmartre cabaret, launched in 1882 and hosting two famous series of graphic narratives. Adolphe Willette's and Théophile Steinlein's stories were devoted to the iconic figure of Pierrot and a gallery of black and white cats, respectively. Although they owed their success and influence primarily to their innovative use of the purely visual language of the wordless comic strip-already popularised in the previous decade by the German Fliegende Blätter-the use of recurring figures, themes and visual topoi helped them to construct a coherent body of works.

Once again, the application of "narrative" to these serial images is a loose one. Inspired by previous examples of wordless comics, the shows featured in the cabaret, and the experimental scene of Montmartre, the comic strips of the Chat noir (usually one-page in length) focused on the "attractional" power of their purely visual language, emphasising movement, speed, and bodily transformations. These characteristics connect the work of Willette and Steinlein to the larger cultural and aesthetic context of nineteenth-century print and visual culture, in which practices of serialisation generate an endless proliferation of images and texts. However, the serial element of the comics of Le Chat noir turns a structural feature of the comic strips of their time into an explicit theme, capable of revealing its symptomatic meaning. Beyond the spectacular, kaleidoscopic effect of their actions, the repetition of Pierrot's absurdist ("fumiste") exploits and the cats' instinctual behaviour reveal them to be fragmented, multiple subjects, entirely consisting of bodies in movement.

Even if the use of "recurring characters" in these comic strips can be clearly opposed to the very notion of a "serial hero", the "serial figures" chosen by Willette and Steinlein have an affinity with Töpffer's notion of the ideal protagonist of what he called littéerature en estampes. The use of a traditional and universal figure, such as Willette's Pierrot or Steinlein's cats, reflects an interest in reworking well-known imagery (whether taken form popular theatre or everyday life). As the Swiss writer stressed in his theoretical works, by adopting this type of figures, an artist can explore the infinite opportunities provided by the well-known background of the character. Moreover, the subversion of the public's expectations is reinforced by references to a shared imagination. The 
slapstick comedy and black humour that characterise the comics published in Le Chat noir are based on their reworking, and subversion, of popular icons. Willette's and Steinlein's inclusion of such references, while marginal in nineteenth-century graphic narratives, resonates with the role that intertextual operations, such as adaptation, plagiarism, and parody, would play in the following decades, both in the field of comics and in that of the avant-gardes.

By moving a figure such as Pierrot from the theatre stage to the comic page, Willette anticipated a fundamental strategy of early cinema, as well as the later slapstick comedy, which transformed the physical gags of vaudeville actors into more abstract graphic gags. It is not a coincidence that as famous an actor as Charlie Chaplin often acknowledged his debt to the (British) comic strips of the 1890s, which in turn owed quite a bit to vaudeville and music hall shows. The tramp characters to whom Chaplin often paid homage (Happy Hooligan, Weary Willie and Tired Tim) ${ }^{16}$ gave birth to stage and film adaptations, as was the case a few years earlier for the aforementioned (and similarly proletarian) Ally sloper. Coming well before these productions, and having a large transnational circulation and influence, the comics appearing in Le Chat noir must be seen as another ingredient of the inextricable network of intermedial exchanges that extend from nineteenth-century graphic narratives to twentieth-century cinema. These influences would eventually find their way back to the field of comics, deeply influenced by the movies.

\section{Conclusion} practices at a time when this process was not as central as it would later become in the field of comics. In particular, the examples cited in this article refer to various types of serial texts, including:

41 - The book series (e.g. Collection des Jabots)

42 - The serialised story (e.g. Töpffer/Cham's M. Cryptogame in L'Illustration; Petit's Histoires campagnardes)

43 - The recurring character (e.g. Ross's and Duval's Ally Sloper; Willette's Pierrot)

44 - The use of self-contained graphic narrative as a regular feature of humour periodicals (e.g. the graphics narratives published in Fliegende Blätter)

45 - The use of graphic narratives in the illustrated news magazines (e.g. the Christmas issues of The Illustrated London News; the reader's travel reports in The Graphic; the cover page of The Illustrated Police News).

This list of heterogeneous types of serialisation highlights the marginal position of graphic narratives in relation to other, more dominant media. In the case of the nineteenth century, these were the album of caricatures and the satirical, illustrated, or news magazines.

47

It is crucial to consider, however, that this marginality would remain a structural feature of comics even in the following century, particularly in relation to cinema (Stefanelli 2012). In this respect, it is interesting to consider Thierry Groensteen's description of the 
institutionalisation of comics in France at the beginning of the twentieth century. According to Groensteen, the key components of this "major revolution" included:

1. The definitive identification of comics with the periodical press, as opposed to the situation in the nineteenth century, in which the alternative (töpfferian) model of the album was still an influential model

2. The adoption of narrative serialisation (especially the use of recurring characters) as their standard format

3. Their (exclusive) inclusion in the field of children's literature (Groensteen 2009, 28-29).

While the third element was not an essential factor-as the contemporary case of American newspaper comics makes clear-the complete assimilation of graphic narratives into the field of the periodical press is exactly what made narrative serialisation one of the crucial features of their new identity in the twentieth century. In fact, this identification was simultaneous with the appearance of new publication formats in which "comics" became one of the principal features-not coincidentally, in the same period in which this very term started to be used in English with this meaning. This happened precisely with the emergence of the British comic magazines inspired by the launch of Harmsworth's Comic Cuts in 1890, the American Sunday pages in the second half of the 1890s, and the French illustrés for children in the early 1900s. This phenomenon clearly shows that it is only by looking at a larger context that we can understand how multiple factors contributed to the different fates of graphic narratives in the nineteenth and twentieth century.

\section{BIBLIOGRAPHY}

Bailey, Peter. 1983. “Ally Sloper's Half Holiday: Comic Art in the 1880s”. In History Workshop, no. 16, pp. 4-31.

Carpenter, Kevin. 1983. Penny Dreadfuls and Comics: English Periodicals for Children from Victorian Times to the Present Day. London: Victoria and Albert Museum.

Dierick, Charles, and Pascal Lefèvre (eds). 1998. Forging A New Medium, The Comic Strip in the Nineteenth Century. Brussels : VUB University Press.

Filliot, Camille. 2012. "L'invitation au voyage dans les premières bandes dessinées d'expression française". In Nevieuème Art, August, URL: http://neuviemeart.citebd.org/spip.php?article434; English version in SIGNs, Studies in Graphic Narrative, no. 2, December 2011, p. 15-36.

Gaudreault, André, and Philippe Marion. 2005. “A Medium is Always Born Twice”. In Early Popular Visual Culture, vol. 3, no. 1, May, pp. 3-15.

Gifford, Denis. 1976. Victorian Comics. London: Allen and Unwin.

Groensteen, Thierry (ed). 2009. Bande dessinée : son histoire et ses maîtres. Paris ; Angoulême : Skira Flammarion; La cité internationale de la bande dessinée et de l'image.

---. 2013. “De l'art séquentiel à l'art ludique", Textimage, Varia 3, Winter, http://www.revuetextimage.com/07_varia_3/groensteen1.html. 
---. 2010. “L'histoire de la bande dessinée : singularités et perspectives". In Le site de Thierry Groensteen, URL : http://www.editionsdelan2.com/groensteen/spip.php?article12.

---. 2000. Maîtres de la bande dessinée européenne. Paris : Bibliothèque nationale de France : Seuil.

---. 2014. M. Töpffer invente la bande dessinée, Bruxelles : Les Impressions Nouvelles.

---, and Benoit Peeters. 1994. Töpffer : l'invention de la bande dessinée. Paris: Hermann.

Grove, Laurence. 2005. “BD Theory Before the Term ‘BD’ Existed”. In Charles Forsdick, Laurence Grove, and Libbie McQuillan (eds). The Francophone Bande Dessinée. Amsterdam; New York, NY: Rodopi.

Gunning, Tom. 1986. "The Cinema of Attraction: Early Film, Its Spectator, and the Avant-Garde", Wide Angle, vol. 8, nos. 3-4.

Haining, Peter. 1989. Charlie Chaplin: A Centenary Celebration. London: W. Foulsham \& Co.

Harvey, Robert C. 1998. Children of the Yellow Kid: The Evolution of the American Comic Strip. Seattle: Frye Art Museum in association with the University of Washington Press.

Kunzle, David. 1992. "Busch Abroad: How a German Caricaturist Willy Nilly Helped Launch the New Cheap Comic Magazines in Britain and the United States". In Victorian Periodicals Review, vol. 25, no. 3, Fall, pp. 99-108.

---. 1990. The History of the Comic Strip: The Nineteenth Century. Berkeley: University of California Press.

---. 2007. Father of the Comic Strips: Rodolphe Töpffer. Jackson: University Press of Mississippi.

---. 1986. “Marie Duval and Ally Sloper”. In History Workshop, no. 21, Spring, pp. 132-140.

Lefèvre, Pascal. 2009. "The Conquest of Space: Evolution of Panel Arrangements and Page Layouts in Early Comics Published in Belgium (1880-1929)". In European Comic Art, vol. 2., no. 2, pp. 227-252.

Mainardi, Patricia. 2006. "The Invention of Comics". In Nineteenth-Century Art Worldwide, vol. 6, no. 1, Spring, URL: http://www.19thc-artworldwide.org/index.php/spring07/145-the-inventionof-comics.

Maigret, Eric, and Matteo Stefanelli (eds). 2012. La Bande Dessinée : Une Médiaculture. Paris : Armand Colin, INA editions.

Renonciat, Anne. 2000. “Les imagiers européens de l'enfance”. In Thierry Groensteen (ed). Les Maîtres de la bande dessinée européenne. Paris : Bibliothèque Nationale de France ; Seuil.

Sabin, Roger. 2003. “Ally Sloper : The First Comics Superstar ?". In Image\&Narrative, no. 7, October, URL: http://www.imageandnarrative.be/inarchive/graphicnovel/rogersabin.htm.

Smolderen, Thierry. 2012a. "Les bandes dessinées du Graphic et de l'Illustrated London News :

II : Les suppléments de Noël et d'été". In Neuvième Art, January, URL: http://

neuviemeart.citebd.org/spip.php?article359.

---. 2012b. "Les bandes dessinées du Graphic et de l'Illustrated London News : III. Les bandes dessinées journalistiques du Graphic et de l'Illustrated London News". In Neuvième Art, January, URL: http://neuviemeart.citebd.org/spip.php?article358.

---. 2012c. "Histoire de la bande dessinée : questions de méthodologie”. In Eric Maigret and Matteo Stefanelli (eds.), La Bande dessinée : une médiaculture. Paris, Armand Colin, pp. 71-90. 
---. 2009. Naissances de la Bande Dessinée : de William Hogarth à Winsor McCay. Bruxelles : Les Impressions Nouvelles.

Stefanelli, Matteo. 2012. "Conclusion : Aux marges d'une ambiguïté médiaculturelle : quatre questions brûlantes pour une théorie culturelle de la bande dessinée". In Eric Maigret and Matteo Stefanelli (eds.), La Bande dessinée : une médiaculture. Paris, Armand Colin, pp. 71-90.

Waugh, Coulton. 1947. The Comics. New York: Macmillan Co..

Willems, Philippe. 2012. "Nadar and the Serial Image". In Nineteenth-Century Art Worldwide, vol. 11, no. 3, Autumn, URL: http://www.19thc-artworldwide.org/index.php/autumn12/willems-nadarand-the-serial-image.

\section{NOTES}

1. Interestingly, his description would be much less convincing today, for instance because of the increasing popularity of "graphic novels" (see Smolderen 2009: 5-7).

2. See the debate between Thierry Smolderen (2012c) and Thierry Groensteen (2013).

3. The original book, released in Geneva by Schmid, has been digitized by Gallica and it is available at: http://gallica.bnf.fr/ark:/12148/btv1b8529034f/f1.item. An English translation was published in Ellen Wiese, Rodolphe Töpffer, Enter: the Comics, Lincoln, University of Nebraska Press, 1965.

4. The original text was published in the Bibliothèque universelle de Genève in two instalments: no. 1, January 1836, pp. 42-61, and no. 4, April 1836, pp. 314-341; this publication is available through Google Books.

5. This is the whole list of the volumes: Anonymous, M. Jabot (1839); Anonymous, Mr. Crépin (1839); Anonymous, Mr. Vieux-Bois (1839); Cham, Mr. Lajaunisse (1839); Cham, Mr. Lamélasse (1839); Edmond Forest, Histoire de Mr. de Vertpré et de sa ménagère aussi (1840); Cham, Mr. Jobart. Mésaventures d'un homme naïf (1840); Cham, Deux vieilles filles vaccinées à marier. Tribulations de famille (1840); Cham, Un génie incompris (M. Barnabé Gogo) (1841); Cham, Histoire du prince Colibri et la fée Caperdulaboula (1842); Cham and Fénélon, Aventures de Télémaque, fils d'Ulysse (1842); Gustave Doré, Les Travaux d'Hercule (1847).

6. The extremely interesting correspondence between Cham and Töpffer has been recently reprinted in Groesteen 2014, pp. 231-239.

7. Only two other (serialised) comic strips published in the pages of this magazine are usually remembered by scholars: Les aventures de Scipion l'Africain by Benjamin Roubaud, two episodes of which appeared in 1847 (see Filliot 2012) and Aventures [sentimentales et dramatiques] de M. Verdreau by Stop, six episodes of which were published in 1850 (Smolderen 2012).

8. It should be noted that this story was an abridged version of an album previously released by Aubert the same year.

9. For a listing and an in-depth analysis of this corpus see Camille Filliot, "L'invitation au voyage dans les premières bandes dessinées d'expression française: une excursion dans le corpus graphique du XIXème siècle", Neuvième Art, August 2012, http://neuviemeart.citebd.org/ spip.php?article434.

10. As it is well-known, Doré abandoned caricature altogether, and devoted himself to the more highbrow fields of literary illustrations and painting. See Mainardi 2007: "Early comic book artists found their work ill-paid and undervalued, so it is no surprise that they so often took their talents elsewhere. Soon after the publication of Holy Russia, Doré's illustrations of Rabelais were greeted with such acclaim that he decided to devote himself entirely to the more prestigious media of painting and book illustration". 
11. See Antoine Sausverd, “'Les Mésaventures de M. Bêton' par Léonce Petit”, in the blog Töpfferiana, July 18, 2013, URL: http://www.topfferiana.fr/2013/07/les-mesaventures-de-mbeton-par-leonce-petit/.

12. See Antoine Sausverd, “'Comment on devient réactionnaire' par Léonce Petit”, in the blog Töpfferiana, May 19, 2012, URL: http://www.topfferiana.fr/2012/05/comment-on-devientreactionnaire-par-alfred-le-petit-3/.

13. "A total of ninety-eight issues from 1872 to 1882 - or one in every five - and occupied a total of 252 pages - or one in every sixteen" (Kunzle 1990: 159).

14. On the transnational circulation of Busch's works, as well as their countless imitations and plagiarism, see Kunzle 1992.

15. Interestingly, however, the very first recurring character in the field of graphic narratives seems to have been that of Der Staatshämorrhoidarius by Franz Pocci, published precisely in Fliegende Blätter from 1845 (Kunzle 1990: 215-218).

16. For the relationship between Chaplin and comics see Haining 1989, pp. 111-115.

\section{ABSTRACTS}

While the connection between seriality and comics in the twentieth century has frequently been a subject of study, far less attention has been paid to the role of serialisation in the previous century, when the language of comics gradually developed in the illustrated and satirical press. This article discusses a heterogeneous group of graphic narratives published in various European countries between the 1830 s and the 1880 s, before a new generation of comic magazines influenced by American newspaper strips, transformed this emerging field into the autonomous medium of comics. Serial works flourished during this period and included diverse modes, such as series of "graphic novels," the use of recurring characters, the serialisation of picture stories in humour periodicals, and the use of graphic narratives as a regular feature in the illustrated news magazines. By providing a panoramic survey of various types of serial texts, the article suggests that the hybrid nature of these graphic narratives and the publishing strategies applied to them can be better understood if considered in relation to the larger context of nineteenthcentury print culture, rather than in comparison with the future of the medium.

\section{AUTHOR}

\section{FEDERICO PAGELLO}

Federico Pagello was awarded his PhD in Film Studies from the University of Bologna in 2009. He has worked as a postdoctoral researcher at the Universities of Bologna and Limoges, and he is currently Research Fellow of the Institute for Collaborative Research in the Humanities at Queen's University Belfast. His research focuses on the transmediality and the transnational circulation of popular culture, with a specific interest in the relationships between film, comics and genre literature. He has published a monograph on the image of the metropolis in Hollywood adaptations of superhero comic books (Grattacieli e superuomini: L'immagine della metropolis fra cinema e fumetto, Le Mani: 2010), and various articles and book chapters on early twentiethcentury crime fiction and film (including “A.J. Raffles and Arsène Lupin in Literature, Theatre, 
and Film: On The Transnational Adaptations of Popular Fiction (1905-1930)," Adaptation, 6:3, 2013, "Transnational Fantômas: The Influence of Feuillade's Series on International Cinema during the 1910s" in Belphégor, 11:1, 2013; and "The Myth of the Gentleman Burglar: Models of Serialization and Temporality in Early Twentieth-Century Crime Fiction," in J. Anderson, C. Miranda, B. Pezzotti (eds.), Serial Crime Fiction: Dying for More (Palgrave Macmillan: 2015) 